\title{
Two Cases of Tuberculosis Manifesting as Cutaneous Solitary Mass in Patients with Adult T-Cell Leukemia/Lymphoma
}

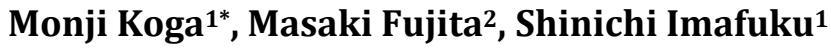 \\ ${ }^{1}$ Department of Dermatology, Faculty of Medicine, Fukuoka University, Fukuoka, Japan \\ ${ }^{2}$ Department of Respiratory Medicine, Fukuoka University School of Medicine, Fukuoka, Japan \\ Email: ^momob3@yahoo.co.jp
}

How to cite this paper: Koga, M., Fujita, M. and Imafuku, S. (2016) Two Cases of Tuberculosis Manifesting as Cutaneous Solitary Mass in Patients with Adult T-Cell Leukemia/Lymphoma. Journal of Tuberculosis Research, 4, 134-139.

http://dx.doi.org/10.4236/jtr.2016.43016

Received: August 4, 2016

Accepted: September 4, 2016

Published: September 7, 2016

Copyright $\odot 2016$ by authors and Scientific Research Publishing Inc. This work is licensed under the Creative Commons Attribution International License (CC BY 4.0).

http://creativecommons.org/licenses/by/4.0/ (c) (i) Open Access

\begin{abstract}
Tuberculosis (TB) is a major public health problem worldwide and a large number of fatal cases are still reported. Immunocompetent individuals are naturally susceptible to $\mathrm{TB}$, and immunocompromised patients have a greater risk of infection. Although patients with adult T-cell leukemia/lymphoma (ATL) are in an immunosuppressed condition, there is only one reported case of TB accompanied with ATL in the Englishlanguage literature in the field of dermatology. Here, we report two patients with chronic-type ATL infected with TB manifesting as cutaneous solitary masses. Case 1 was a 58-year-old woman diagnosed with lumbar abscess with pulmonary TB. Case 2 was an 84-year-old woman diagnosed with tuberculous lymphadenitis in the left cervical region. It is important to raise the differential diagnosis of TB and perform tissue culture for acid-fast bacilli as well as Interferon-Gamma release assay test when dermatologists encounter mass lesions in patients with ATL.
\end{abstract}

\section{Keywords}

Tuberculosis, Tuberculous Lymphadenitis, Immunosuppression, Adult T-Cell Leukemia/Lymphoma, Regulatory T-Cell

\section{Introduction}

Adult T-cell leukemia/lymphoma (ATL) is a mature CD4-positive T-cell lymphoma caused by infection with human T-cell lymphotropic virus type-1 (HTLV-1). Most cases of ATL belong to HTLV-1-endemic areas in southwestern Japan, Central Africa and the Caribbean Basin [1] [2].

It is well known that patients with ATL are more susceptible to various infections. 
Non-specific skin manifestations have been investigated for infections such as leprosy, scabies and superficial mycoses, which can frequently be complicated with ATL, resulting from immunosuppression caused by tumor progression [3]-[6]. With regard to tuberculosis (TB), one review suggests that patients with ATL have an increased risk of TB compared with the general population without ATL [7]. However, no epidemiological evidence, or even a case series, has yet been reported on this issue.

Here, we report two cases of TB manifesting as cutaneous solitary masses in patients with ATL, and discuss the pathoetiology about the relation between ATL and TB.

\section{Case}

\subsection{Case 1}

A 58-year-old woman had been treated with antibiotics for lobular pneumonia which had not been identified the infected organism in a municipal hospital since early August 2010. Although her general symptoms improved with antibiotic treatment, she required careful observation by her attending physician because of residual pulmonary opacity. In late August 2010, she had an uncomfortable feeling at her waist. Then, she was referred to our outpatient clinic. Physical examination revealed an elevated subcutaneous mass with slight tenderness in the lumbar region (Figure 1(a)). T1-weighted magnetic resonance imaging of the lumbar lesion demonstrated a well-defined, low-intensity area measuring $\sim 7 \mathrm{~cm}$, suggesting a large abscess in the subcutaneous/ intramuscular lesion (Figure 1(b)). A test incision revealed widespread yellowish necrotic tissue in the subcutaneous tissue (Figure 1(c)), and no pus discharge. Culture of the necrotic tissue generated acid-fast bacilli, and DNA testing identified Mycobacterium tuberculosis. The interferon-Gamma release assay (IGRA): Quanti-FERON-TB, was also positive. Detailed questions confirmed that she had had a family member with pulmonary TB. Computed tomography revealed a pulmonary shadow on the S6 area in the left lung, suggesting active TB (Figure $1(\mathrm{~d})$ ). The results of hematological examination were as follows: total lymphocytes in white blood cells, $5760 / \mu \mathrm{L}$; atypical lymphocytes, $4630 / \mu \mathrm{L}$ ( $>5 \%$ total lymphocytes); soluble interleukin-2 receptor, $5047 \mathrm{U} / \mathrm{mL}$; and lactate dehydrogenase, $211 \mathrm{IU} / \mathrm{L}$. And serum albumin and BUN were within normal range. Serologically, anti-HTLV-1 antibody was positive. Based on these findings, we diagnosed this case as pulmonary and subcutaneous TB in association with chronictype ATL. Combined chemotherapy with isoniazid (INH), ethambutol (EB), rifampicin (RIF) and pyrazinamide (PZA) was started, and all lesions of TB were improved by 6 months after treatment.

\subsection{Case 2}

An 84-year-old woman had been visiting an internist regularly for chronic-type ATL without any medication. Her condition of ATL had been stable for the past few years without any indications of poor prognosis on her peripheral blood. She had no familial or past history of TB. One day, she noticed a left cervical nodule measuring $\sim 1 \mathrm{~cm}$ in diameter. The nodule had enlarged gradually despite oral cephem antibiotics. She was 


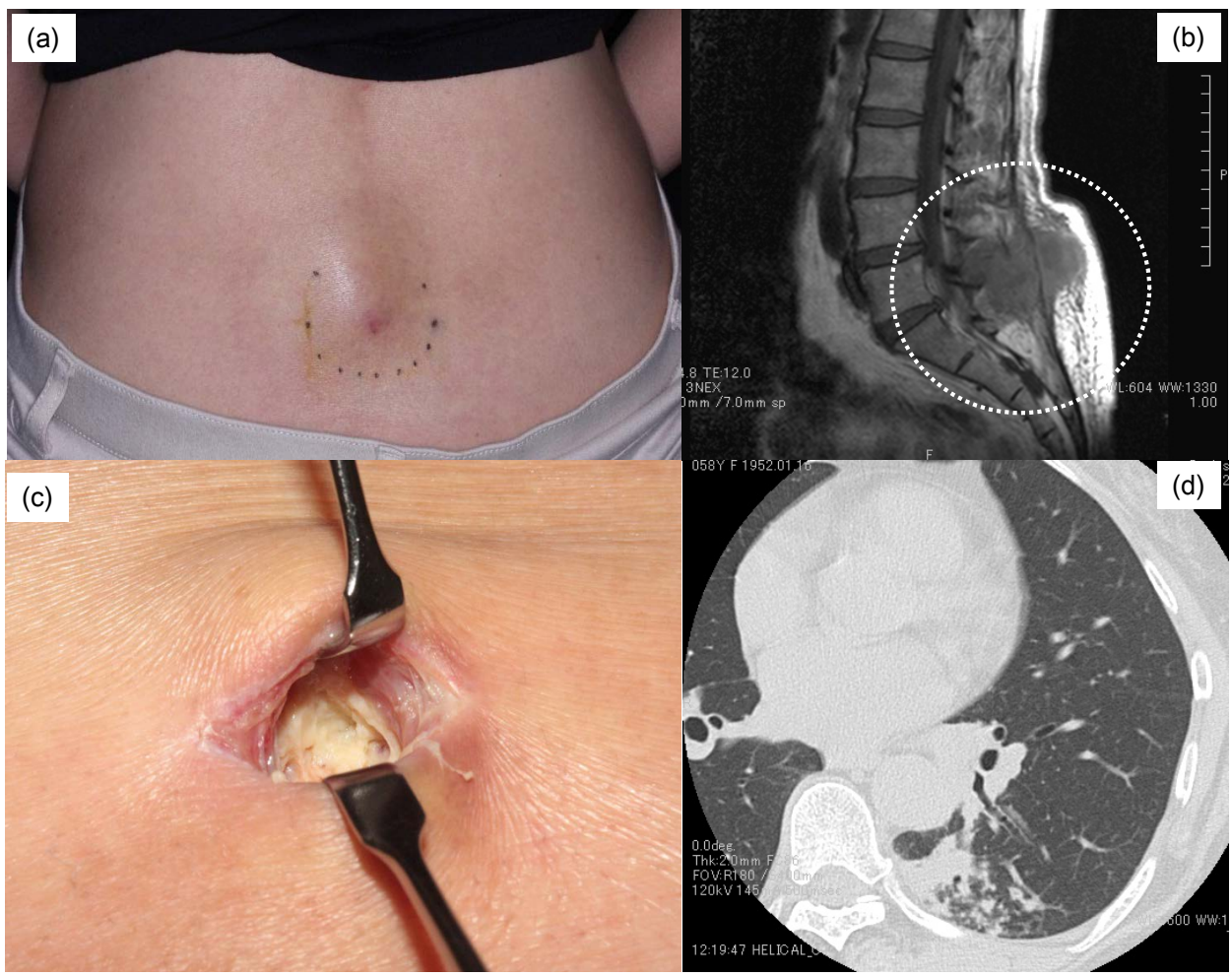

Figure 1. Clinical appearance $(a, c)$, results of magnetic resonance imaging and computed tomography (b, d) in Case 1. (a) Mass lesion with slight tenderness in the lumbar region was observed. (b) Well-defined, low-intensity area measuring $\sim 7 \mathrm{~cm}$, suggesting a large abscess developing from the subcutaneous/intramuscular lesion. (c) Widespread yellowish necrotic tissue was seen in the subcutaneous tissue. (d) Pulmonary infiltrates with satellite lesion in S6 of the left lung, suggesting active tuberculosis.

referred to our outpatient clinic with suspicion of skin involvement of acid-fast bacillus infection.

At the first visit, she had no respiratory symptoms such as cough and sputum. She presented with a hard brownish nodule measuring $3 \mathrm{~cm}$ in diameter with symptoms on the left aspect of the neck (Figure 2(a)). Culture taken from the lesion generated acid-fast bacilli confirmed as $M$. tuberculosis by polymerase chain reaction. No acid-fast bacilli or other organisms were detected in her sputum. The result of IGRA, T-spot TB was negative. Imaging revealed swollen lymph nodes around the left cervical lesion without any other active focus of TB (Figure 2(b)), and we confirmed diagnosis of tuberculous lymphadenitis. We started combination chemotherapy (RIF, PZA, INH, EB), and 1 year after the lesion has almost disappeared.

\section{Discussion}

ATL often manifests with non-specific skin lesions for some infections such as leprosy, scabies and superficial mycoses, in addition to the specific tumoral skin lesions [3]-[6]. As previously investigated, tumor cells of ATL typically express CD4, CD25 and often fork head box P3, which are matched with a phenotype of probable origin, regulatory 


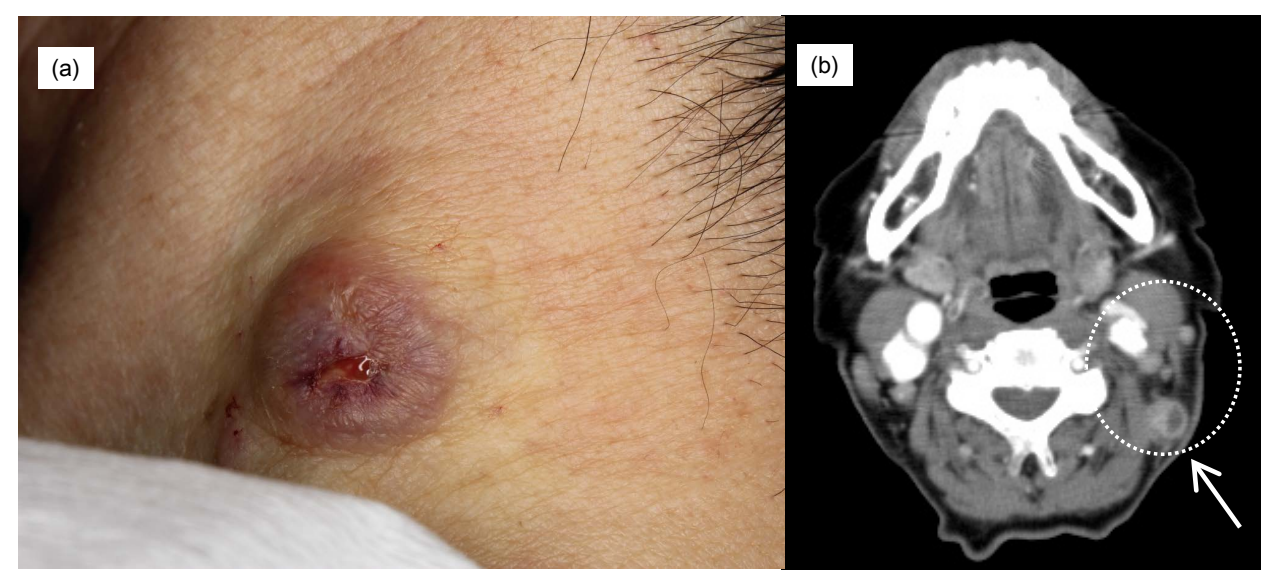

Figure 2. Clinical appearance (a) and computed tomography (b) in Case 2. (a) The lesion presented as a hard brownish nodule measuring $3 \mathrm{~cm}$ in diameter with no signs on the left cervical region. (b) Multiple lymph node swellings were found in the left cervical region.

$\mathrm{T}$ (Treg) cells. Although the exact etiology of increased susceptibility to some infections in patients with ATL has not yet been clarified, it has been speculated that tumor cells and/or nontumoral Treg cells might contribute to the immunosuppression [2] [4] [5].

Immunity mediated by $\mathrm{T}$ helper 1 cells has been shown to be responsible in $M$. tuberculosis infection [8]-[10], and the mediator, interferon gamma, produced by peripheral blood mononuclear cells has been quantified by IGRA (Quanti-FERON-TB Gold test and T-spot TB) for screening of TB. The T-spot TB test was negative in Case 2 , suggesting that her $\mathrm{T}$ helper 1 immunity was impaired. IGRA has high sensitivity to detect $M$. tuberculosis infection, however, it should be kept in mind that IGRA measures host response as evidence of infection. Therefore, it can be negative in immunosuppressed patients, and Kobashi et al. have reported that IGRA shows false-negative results more frequently in immunosuppressed patients [11].

With regard to the relation between Treg cells and TB, one report states that patients with TB have more Treg cells in their peripheral blood compared with healthy controls [12]. Another study demonstrated that Treg-cell-depleted mice infected with TB have a low bacterial load in the lungs after aerosol infection [13]. These findings indicate that activation of Treg cells helps progression of $\mathrm{TB}$, and it could be interpreted that patients with ATL have a greater risk of being infected with TB.

Although there are many reports of TB complicated with immunosuppression, such as acquired immunodeficiency syndrome, to the best of our knowledge, there is only one reported Japanese case of cutaneous TB with ATL in the English-language literature [14]. That case was a 65-year-old man with multiple reddish plaques and erythema around the head who was diagnosed with multifocal lupus vulgaris. And there have been no reported cases of TB manifesting as cutaneous solitary mass in patient with ATL except for true-cutaneous tuberculosis and tuberculid. With more cases accumulated, we may be able to clarify the incidence and predominant type of cutaneous involvement of TB and clinical type of ATL. 


\section{Conclusion}

We emphasize here that TB is one of the important differential diagnoses when dermatologists encounter tumoral lesions in patients with ATL, and one should perform an acid-fast bacillus culture as well as IGRA test.

\section{Conflict of Interest}

None declared.

\section{References}

[1] Ohshima, K., Jaffe, E.S. and Kikuchi, M. (2008) Adult T-Cell Leukemia/Lymphoma. In: Swerdlow, S.H., Campo, E., Harris, N.L., et al., Eds., WHO Classification of Tumors of Haematopoietic and Lymphoid Tissues, 4th Edition, IARC, Lyon, 281-284.

[2] Tokura, Y., Sawada, Y. and Shimauchi, T. (2014) Skin Manifestations of Adult T-Cell Leukemia/Lymphoma: Clinical, Cytological and Immunological Features. The Journal of Dermatology, 41, 19-25. http://dx.doi.org/10.1111/1346-8138.12328

[3] Kabashima, R., Kabashima, K., Hino, R., Shimauchi, T. and Tokura, Y. (2008) Scabies Superimposed on Skin Lesions of Adult T-Cell Leukemia/Lymphoma: Case Report and Literature Review. International Journal of Dermatology, 47, 1168-1171. http://dx.doi.org/10.1111/j.1365-4632.2008.03707.x

[4] Dantas, L., Netto, E., Glesby, M.J., Carvalho, E.M. and Machado, P. (2014) Dermatological Manifestations of Individuals Infected with Human T Cell Lymphotropic Virus Type I (HTLV-I). International Journal of Dermatology, 53, 1098-1102. http://dx.doi.org/10.1111/ijd.12170

[5] Qayyum, S. and Choi, J.K. (2014) Adult T-Cell Leukemia/Lymphoma. Archives of Pathology \& Laboratory Medicine, 138, 282-286. http://dx.doi.org/10.5858/arpa.2012-0379-RS

[6] Amano, M., Setoyama, M., Grant, A. and Kerdel, F.A. (2011) Human T-Lymphotropic Virus 1 (HTLV-1) Infection-Dermatological Implications. International Journal of Dermatology, 50, 915-920. http://dx.doi.org/10.1111/j.1365-4632.2011.04882.x

[7] Marsh, B.J. (1996) Infectious Complications of Human T Cell Leukemia/Lymphoma Virus Type I Infection. Clinical Infectious Diseases, 23, 138-145. http://dx.doi.org/10.1093/clinids/23.1.138

[8] Khader, S.A., Bell, G.K., Pearl, J.E., et al. (2007) IL-23 and IL-17 in the Establishment of Protective Pulmonary CD4+ T Cell Responses after Vaccination and during Mycobacterium tuberculosis Challenge. Nature Immunology, 8, 369-377. http://dx.doi.org/10.1038/ni1449

[9] North, R.J. and Jung, Y.J. (2004) Immunity to Tuberculosis. Annual Review of Immunology, 22, 599-623. http://dx.doi.org/10.1146/annurev.immunol.22.012703.104635

[10] Cooper, A.M. and Khader, S.A. (2008) The Role of Cytokines in the Initiation, Expansion, and Control of Cellular Immunity to Tuberculosis. Immunological Reviews, 226, 191-204. http://dx.doi.org/10.1111/j.1600-065X.2008.00702.x

[11] Kobashi, Y., Abe, M., Mouri, K., Obase, Y., Miyashita, N. and Oka, M. (2012) Usefulness of Tuberculin Skin Test and Three Interferon-Gamma Release Assays for the Differential Diagnosis of Pulmonary Tuberculosis. Internal Medicine, 51, 1199-1205. http://dx.doi.org/10.2169/internalmedicine.51.5703

[12] Singh, A., Dey, A.B., Mohan, A., Sharma, P.K. and Mitra, D.K. (2012) Foxp3+ Regulatory T Cells among Tuberculosis Patients: Impact on Prognosis and Restoration of Antigen Specific IFN- $\gamma$ Producing T Cells. PLoS One, 7, e44728. 
http://dx.doi.org/10.1371/journal.pone.0044728

[13] Scott-Browne, J.P., Shafiani, S., Tucker-Heard, G., et al. (2007) Expansion and Function of Foxp3-Expressing $\mathrm{T}$ Regulatory Cells during Tuberculosis. The Journal of Experimental Medicine, 204, 2159-2169. http://dx.doi.org/10.1084/jem.20062105

[14] Hamada, M., Urabe, K., Moroi, Y., et al. (2004) A Case of Multifocal Lupus Vulgaris That Preceded Pulmonary Tuberculosis in an Immune Compromised Patient. The Journal of Dermatology, 31, 124-128. http://dx.doi.org/10.1111/j.1346-8138.2004.tb00521.x

\section{Submit or recommend next manuscript to SCIRP and we will provide best service for you:}

Accepting pre-submission inquiries through Email, Facebook, LinkedIn, Twitter, etc. A wide selection of journals (inclusive of 9 subjects, more than 200 journals)

Providing 24-hour high-quality service

User-friendly online submission system

Fair and swift peer-review system

Efficient typesetting and proofreading procedure

Display of the result of downloads and visits, as well as the number of cited articles Maximum dissemination of your research work

Submit your manuscript at: http://papersubmission.scirp.org/ 